\title{
Adam Goodman, service producer
}

Adam Goodman is a producer and co-owner of Mid Atlantic Films in Budapest, Hungary. He has contributed to numerous projects over the past twenty years, most recently A Good Day to Die Hard (2013), World War Z (2013), and The Martian (2015). Reflecting on Budapest's emergence as a leading production locale in Eastern Europe, Goodman explains the challenges of managing transnational production logistics and up-skilling his core network of contract employees.

You operate one of the premier service firms in Budapest, but you've said you're still anxious about securing contracts. Why?

It's an anxiety that comes from a lifelong freelance mentality-you're only as good as your last job. And you only know that you did a good job when you're called for the next project. I was talking about this very thing the other day to my business partner Howard Ellis. I said, "The same buzz, the same high I got when I got a phone call asking, 'Are you available to get on a plane?' is the high I get now when someone asks, 'Are you available to service our film?"' But I'm a managing director now, which gives me even more anxiety. As a freelance line producer [before starting Mid Atlantic in Budapest] I had the flexibility to follow the work, which expanded my opportunities. I was only responsible for myself. As a service producer, I'm responsible for our company and the livelihoods of those who work with us. And our success is contingent upon producers wanting to come to Hungary.

It's turned out okay for us. In our early days, we never knew what we were doing in an upcoming year until just before Christmas, or more likely in the first quarter 
of the new year. Now we're working on budgets for shows that may or may not happen more than a year in advance.

\section{What do you think is driving this change?}

It's like running a good restaurant-the more people come here, the more buzz it generates, the more business we receive. We're now an established location. Since Hungary got its new tax rebate in 2004, which was instrumental in putting us on the production map, we've continued to draw business away from Prague. As business continued to develop here, so too did producers' confidence and comfort. And the fact that we established our reputation as part of that momentum means we've successfully positioned ourselves as a key partner in the region.

But as you say, your success is contingent on other factors outside of your direct control, especially the incentive.

We're actively involved in lobbying the Hungarian government to preserve and improve the incentive. It involves a lot of meetings with politicians, lawyers, accountants, film commissioners, and other producers. For instance, when the incentive was last up for review by the EU commission, we-the proverbial "we" being tax advisors from Ernst \& Young-put together a proposal to increase the value of the incentive. We didn't simply ask to have what we had before. We thought, let's get creative. Let's do something unique. E\&Y agreed. We added a foreign spend element to the tax rebate. Production companies get a rebate not only on what they spend here but also on what they spend outside of Hungary on Hungarian labor. So you now can take your Hungarian crew to Jamaica for a few weeks of location shooting, and you'll get a rebate on those labor costs.

It's been incredible for business here. But I know it really hurt Prague. It's symptomatic of any economy, not just the film business: when there isn't enough business to enable people to pay their mortgages and feed their families, they go and do other things. There was some fallout along those lines in Prague. It reduced the crew base-not the skill base-but a lot of crew had to find something else to do to pay their bills.

\section{How quickly?}

Quite frankly, almost immediately after the Hungarian tax rebate kicked in. Prague is marginally more expensive before rebates—but only marginally — and now with our rebate, we're cheaper. Once the Czechs got their tax rebate, we expected to see 
a significant reduction in our cycle of shows. But we didn't, largely because the Czech rebate isn't as competitive.

Ironically, Prague did so much to establish Central Europe as a viable location. There's greater awareness of and interest in shooting here. But when producers start comparing the rebates, they notice two things: one, the Hungarian rebate allows you to maximize spend; and two, the Czech rebate is capped by the national government.

\section{Can you walk us through the steps it takes to put a project together?}

When we first set up Mid Atlantic, our plan was to fly to Los Angeles, knock on the doors of all the people with whom we had ever worked, and start pitching for projects. We had intended to build upon those relationships. But we've never gotten around to taking that flight. We've just been too busy.

The key to our success is based on two very clear criteria: Adam and Howard. It's our address books. It's our reputations as honest, transparent, clear-thinking producers-the same traits that made us good line producers have made us good service producers. Given that people are traveling so far to make a film with so much money at stake, trust is a fundamental aspect of our business and key to our success. It sounds pompous, but you can argue that no one would consider coming here if it wasn't for us.

Of course, it is pompous because we couldn't do anything without the crew base here, which is second to none. We've developed four of the best teams in Hungary since we first started in 2005.

\section{Are they exclusive to you? How much does their fate depend on your company?}

People seem to think we have some kind of mafioso control over the local crew base, but that's not the case. They don't work for us exclusively. Of course, we want them to stay with us, but we always tell them to take the first job that's guaranteed. So if we lose out on a contract, then they're free to find work elsewhere.

Do you find yourself working consistently with the same people? Do you try to keep your crew together as a team?

Absolutely. I know whom I can trust, and I want to work with them. When you hire a production manager, they want their production coordinator. They will have a preference for a particular accountant. When you hire certain heads of departments, they will want to work with certain assistants. Is it particularly clubby, cliquey, and cartel-like? Yes. We work with the top four production managers in the city. Each has their preferences. We've encouraged them to harmonize a bit 
more, but they are pretty committed to their own opinions. And that's the frustration of a lot of new people trying to break into this industry. It's the same anywhere but particularly here because of the scale. It's a smaller, tighter labor pool, so there are fewer ways into the inner circle. It's fiercely guarded.

I get two or three emails each week from young people who say this is the only thing they want to do in the world. And trying to get our group to give them the benefit of a meeting is hard, but I'm very passionate about meeting as many people as I can. I think it's to the benefit of our industry. We need new blood. We already struggle to find crew when there are multiple productions in town. My job is easier when I can say yes to producers' requests. Having more crew allows me to say yes more often.

You can go to film school in Hungary for five years and spend two million forints [approximately US \$7,000] on tuition but end up unemployed for five years after graduation because I can't integrate you into my crews. I can give you a job as a PA [production assistant] that pays 25,000 forints [approximately US \$85] per day. In Hungary, that's a very good entry-level salary. Plus, it gives you the first credit on your résumé. You start to climb the ladder. So when I recognize completely capable people who could step into these entry-level professions and start to train for more advanced jobs down the road, it drives me absolutely crazy that it's so difficult to integrate them. It makes me so angry. What a waste!

What's causing this? Are the crews too exclusive? Or perhaps the film schools in Budapest and Prague-impressive as they are-have yet to reimagine themselves for a new era of film production. They're training auteurs, not working professionals or craftspeople.

I think there's truth to both explanations. Hungarian crews are very protective. They don't want to dilute the crew base to the point where somebody might get offered the job before them. It's not arrogance or selfishness, but they worry about new blood. They worry about someone shining on set and then replacing them. It's a fundamental insecurity that the nature of this work breeds in the crew. You never want your current job to be your last.

We also struggle with the film schools. I'll often ask my production manager to call the film school when we need additional support-like a camera trainee. You would think that someone who dreams, sleeps, and eats being a director of photography would jump at the chance to work as a trainee under Oscar-winning DPs. In fact, this opportunity to rub shoulders with the best of the best is unique to locations like Budapest. You won't find the same opportunity in Los Angeles so early in your career.

But we can't get them to work. They won't do it for the education. They won't do it for the art. They won't do it for the money. Call it arrogance. Call it snob 
factor. Call it naïveté. They would get rates that most people in this country don't even earn as a bank manager. It's dumbfounding. When I meet someone as a production assistant, I ask, "What do you want to do in this business?" And they say, "I want to be a director." Fantastic! But they want to be a director now. They don't want to train as an assistant director. They don't want to train as an editor. They've got their degree. They've been rubber stamped as knowing everything. But they don't. They don't know what it's like on a set. In fact, I'd rather meet people who don't know exactly what they want to do. They're more willing to jump into the trenches and do whatever work is offered for the chance to learn and hone their craft.

\section{What does the typical crew member look like?}

Demographically? We may have a film student or two, but the biggest issue we face here is that there is not enough regeneration of our crew base. The answer to your question is "mostly older men." Camera operators. Electricians. Construction. We're generally not talking about people in their early twenties or thirties.

It sounds like there isn't a career apprenticeship system or a structured process for advancement.

You're correct. We try to introduce trainees into our budgets when we're calculating costs. On bigger films we'll always put in a camera trainee. We'll aim to include additional grips and electricians and production assistants. Honestly, trainees are cost-effective ways to increase your labor, so it's a win-win. But as I've described to you, it's a problem in Budapest.

I am most concerned about the hair and makeup and costume departments. It's a very old club that's particularly unwelcoming to new faces. It's to their own disadvantage. The current regime can't work forever. Who is going to replace them? I've had to intervene a lot to make sure we're bringing in more entry-level workers in those departments.

Let's talk about on-set dynamics. You have American and British crews alongside Hungarian crews for sixteen-hour days. What sorts of issues does that create?

Certain foreign crew members are very much like good wine. They don't travel well. They're great in L.A., in London, or in Rome. But put them on a plane and bring them to the "evil dark empire" of Eastern Europe? They arrive with expectations for a certain comfort level so out of sync with the reality that they struggle to work here. We call it "casting" the crew. We advise producers that knowing who to hire means knowing who travels best and who doesn't travel 
well at all. Who has to bring their aunts, uncles, mother-in-law, two sisters, and three brothers? And that happens! You hire a very highly respected gaffer, and they say, "Great, I'd love to do the job but just so you know, here's who I'm bringing." A best boy and electrician and suddenly ten names. In those instances, we say to the producer, “This person doesn't need ten people. They need one or two." It's an unrealistic expectation and an unnecessary cost to bring any more than that with you to Budapest, especially in the electrical department. It's one of our key strengths.

It requires the producer to make the decision. Either give the department head what they want, or encourage them to embrace the peculiarities of working in a country that doesn't speak English. "If you want this job, you can only bring one or two people." Problems start to happen when you have foreign crew bringing in coachloads of people. When the balance of power is weighted more toward the foreign hires, then the Hungarians get sidelined and become nothing more than hired hands. There's simply no chemistry. The best composition is a few foreign hires who travel lightly and work with a majorityHungarian crew.

At the same time, I always remind my local crew that they are not equal to their US or UK counterparts. The foreign department head is the boss. End of story. Deal with it. It's never going to change. They have more responsibility and more authority.

\section{Does that pose challenges?}

Communication is our biggest challenge. Different people from different parts of the world communicate in very particular ways: what words they choose, the tone in which they say them, how they use body language. An electrician from Pinewood doesn't enunciate, and suddenly there's a complete clusterfuck because a scaffold is here when it needs to be there. I've been doing this long enough now that I can actually see it happening: a department head is communicating something to the crew, and the crew is nodding along but not understanding. That's when I need to intervene to preempt any problems.

\section{It seems to involve more than just language competency, though.}

Right. There's a different division of labor, too. For example, in America, a key grip sets your flags and your stands but the unions won't allow that person to touch a light. In Hungary, our grips handle camera rigs but they are very happy to move a lamp. Our electricians will handle anything that's connected to a lamp, including hanging them from the ceiling, which in America and the UK would be a rigger. When you enforce those job categories, it causes the crew to grow bigger than 
what you'd find on a Hungarian film. It looks wasteful and unnecessary to local crew. I think sometimes it is!

We had coachloads of foreign crew when we did 47 Ronin (2013). The movie was here only for a short while before returning to the UK, so they wanted continuity in their crew, which is a fair expectation. At one point during the shoot, the Hungarian electricians came to me confused. They needed to run some cables between two stages, and the UK electricians wanted to build a waterfall, which is a really large scaffolding structure. My guys just wanted to put the cables on the floor and run a ramp over them. But the Brits wouldn't have it. UK health and safety regulations required it done a certain way, and that's how they had to do it. So, my guys helped build this monstrous tower with lights and ballasts. It looked like a low-flying aircraft, and cost an extraordinary sum. My guys thought it was hysterical. Why go to all this effort and money when the other way is so much easier?

\section{You mentioned electrical as one of Budapest's strengths. What are others?}

I would say electrical, grip, costume, production management, transportation, and construction. Construction is very, very good here. Fantastic. We are weak in special effects. It's more a question of crew depth. We can represent four really strong teams in pretty much every area. But if one of those teams or a part of those teams is on another show, then you start to feel the pressure. Who do we find now?

\section{Are there creative opportunities for local crew members?}

It's rare. Most of the shows we do here are such high-end productions. They are going to bring their department heads with them. I can think of only one exception: Judit Varga was the set decorator on The Borgias (2011-13). She did a magnificent job, and now has the credits to replace a foreign hire. But there aren't many people like her. There are more opportunities on some of the smaller European coproductions we do, but that's 5 million euro compared to US \$125 million. Let's face it: those are very different budget parameters. If you want to get your 5 million euro movie made, hiring locally helps you do it. Creatively, local people are very capable, but you're not going to do it on a high-end movie.

So what are the key local positions?

I think the production office is a key space for those positions. Production manager. Production coordinator. Service producers often act like line producers. Location managers are an essential local position. We have two of the best location 
managers in the country, and they thankfully work almost exclusively for us at this point. We have been able to keep them busy over the past eight years. It's also an area where I've seen the most opportunities for regeneration. They're open to new blood. It's developing at a slightly faster speed than other areas.

Are foreign producers interested in exteriors or in infrastructure?

It's a question asked in tandem. Shows come here not because Budapest is the best place creatively to shoot but because the numbers work. When Showtime asked us if Budapest was the best place to make The Borgias, we were honest. We said, "No. You aren't going to find a lot of great exteriors to match Renaissance-era Rome. Budapest is nineteenth-century Austro-Hungarian Europe." But the numbers worked. I told them, “There's not a doubt in my mind that we can build whatever you need to shoot here." Conversations with producers are much more productive when you're honest about what you can do. Budapest has a distinct look that isn't going to work for every movie creatively, but we have the skill base here to build what we lack when the numbers work.

Studios have someone whose only job is to chase tax rebates and incentives. There are very few movies over US \$25 million in which anybody cares too much about the location's creative "fit," apart from the director. Producers want it to make money.

But then there's something like Dracula (2013-14), in which there's some creative resonance between the narrative and the location.

Let me put it this way: if there was a cheaper place to make Dracula, they'd be there.

What's more difficult: a blockbuster production like Hercules (2014) or a television series like Dracula?

Hercules.

You didn't hesitate.

It goes back to what I was saying about the right balance between the foreign and the local. It's much easier for the scales of control to spin out of balance on those behemoth Hollywood productions. It's a machine: a fucked-up machine with lots of money, big personalities, and even bigger egos on the line. If the person leading the charge on something like that is a monster, it can throw the whole machine 
out of sync. It trickles down. It can affect everyone on the set, from the top to the bottom. It can feel like you're riding on the back of a headless chicken.

Television is a different budget and a different timeline. Certainly you have obstacles - a lot them have to do with making sure talent is here when you need them to be here because you're putting together an episode each week. But because of the lack of time and money, you don't have the luxury of things spinning out of control. You're much more dependent upon everyone pulling together and collaborating to get this thing done on time and under budget.

Hollywood blockbusters are known for their excesses, not their limitations.

\section{And you're on the front line when those excesses spin out of control.}

The best comical example of this-comical now, not then-is the day that I'm standing in the city's tenth district on the set of World War Z. I receive a call that the weapons we need for the shoot three or four days away have been impounded by the Hungarian Counter-Terrorism Unit after a SWAT team raided the airport. We're talking pistols, machine guns, sniper rifles, and grenade launchers. I need to report to the National Bureau of Investigation for questioning. It was one of the most intense experiences I've ever had.

Here's the long and short of it: British Airways refused to transport the weapons for us. We had all the permits in place, but for whatever reason, they wouldn't do it. The only way we could get the guns here on time was to charter a private jet. So we chartered a private jet. Unfortunately, the problems began when the chartered jet arrived at three in the morning at a smaller airport in the region. Someone called a tip in to national security and here we are with what looks like a chartered plane with a weapons cache arriving in the middle of the night under cover of darkness. It also happened less than two weeks before October 23, which is a very politically charged public holiday in Hungary [marking the start in 1956 of what was a failed rebellion against Soviet-imposed policies]. The plane lands. The tactical team swarms. They're wearing balaclavas with machine guns ready to go. Elsewhere in the city our Hungarian weapons supervisor was marshaled out of his home in his boxers at three in the morning while they raided his residence. I get the call the next day, informing me that I'm under suspicion of arms smuggling because my name was on the permit. So I go in for questioning.

Eventually we were cleared of all charges, but the problem for us-and this goes back to your question about the nuances of this job-was that Hungarian law requires permanent deactivation of all ammunitions used on a film set. Yet in the US and UK, you're only required to put a screw through the barrel to prevent the bullet from exiting. Removing that screw makes the gun a functional weapon and thus not sufficiently modified under Hungarian law. So, it looked like I was smuggling a fully functional arsenal. Obviously we weren't the first production to bring in weapons. 
Productions have been bringing them into the country illegally, probably unknowingly, for years. We just got caught. And we got caught-I think but I can't prove it-because a local ammunitions company that wanted the business turned us in.

As a result of all this, I started a lobbying campaign before the production of A Good Day to Die Hard. I said to Parliament, "Look, you can change the laws or you can lose US $\$ 40$ million in local spend and income when these movies choose another location." It wasn't easy to convince them, but they changed the law-it was a massive legislative change.

It was such a process, and you know what? The scene [that we originally needed the weapons for] didn't even make it into the final cut of World War Z.

It's interesting to note that the most successful service firms in Prague and Budapest are run by American or British expats.

The cultural connection establishes a level of comfort and sense of confidence. A studio doesn't want to spend the level of money they're spending here without working with a known entity. We are the known entity. And we know the value of 1,000 forints. We know what that will buy you. A foreign producer does not. And that makes them vulnerable. Working with us ensures you're not spending 1,000 forints when you could be spending 500 forints. We ensure the studio is maximizing their spend. We ensure they aren't wasting it.

Does the studio's desire to "maximize their spend" ever pose problems? Do you find yourself having to educate producers about production costs in Budapest? Do they sometimes have unreasonable expectations about, for example, labor costs?

I don't know why it's such a challenge to explain this to people, but I often encounter this impression that I can just adjust the crew rate to better fit the budget. Rates don't fluctuate in Budapest. The same rates apply whether you're shooting something at US \$125 million or US \$20 million. Hotels don't adjust their rates. Crews don't adjust their rates. I know it's slightly different in the United States and the UK because of the various union contracts that adjust rates according to budgets. But that doesn't happen here. When I do a budget for a foreign producer, I know what a grip costs. I know what an electrician costs. I know what a hotel room costs and what building materials cost. Yet because they're filming here, they think they can tell me what costs they think are fair. It doesn't work that way-I'm not performing magic. It requires the foreign producer to adopt a different mindset. If your budget is $\$ 20$ million-which is low compared to the productions we normally do here-then you need to decide how much you're able to spend on construction. Producers send us a script and expect a budget the following week, but the process is far more complicated than that. What do you want, and how much can you 
spend? You can spend $\$ 100$ or $\$ 100,000$. I can tell you what each will get you. But you can't tell me the budget line for construction is $\$ 100$ because you think that's appropriate for Budapest when what you want to build will cost $\$ 100,000$.

It is cheaper here. Budapest is generally 25 percent less than Los Angeles. So you will save money, but you can't ask me to price a piece of string without first telling me how long it is.

It sounds like there's a lot of back and forth with producers.

Always. And they're always seeking the best deal. I don't blame them. But I tell them, "Unless you give our budget to a competitor or give a competitor's budget to us, you will never ever hear a true apples-to-apples comparison." Budget lines are easily manipulated. Even when it's not intentional, how information looks on paper is different than how it turns out in practice. For instance, Romania always looks cheaper on paper but you encounter so many problems there that you end up having to bring more people with you than you anticipated, or incur so many unexpected or indirect expenses. How much are you actually saving?

Part of our success is attributed to our honesty. I don't play around with budget numbers. I'll show you what it will cost even if you don't like what you hear. I'll tell a producer that I can't match whatever competitor they're quoting. I'll say, "We can't do it for that cost." If it's an honest budget-and sometimes that's a big "if"the producer is better off going somewhere else.

You're not just protecting your company and your reputation. You're also protecting your crew.

I think we're one of the few companies that operate that way. Others are much more willing to say, "I guarantee that it's cheaper to do it here. Come! Come! Come!" It's such a risky game to play. No one ends up happy when what was promised isn't delivered. 